\title{
Can Cause-Related Marketing (CRM) 'Light' up the Brand Image? An Insight into the Perceptions of Jordanian Consumers
}

\author{
Dr. Tareq N. Hashem \\ Associate Professor, Marketing Department, Isra University, Amman - Jordan \\ Dr. Mohammad Ahmad Niqresh \\ Assistant Professor, Princess Alia University College- Albalqa Applied University, Jordan
}

\begin{abstract}
The main aim of this research study is to examine the influence of Cause-Related Marketing (CRM) campaigns on the perceived brand image, brand loyalty and intention to buy among Jordanian customers. A self-administered questionnaire was distributed to 300 shoppers by using convenience sampling in Amman, Jordan. The results of the study showed that CRM is mainly used by corporations in order to demonstrate their commitment to charitable behavior and Corporate Social Responsibility (CSR). The study revealed that customers in Jordan understand the underlying idea and purpose of CRM practice and have clear perceptions and attitudes about it.
\end{abstract}

Keywords: Cause-Related Marketing (CRM), Brand Image, Purchase Intention, Solidarity Purchase, Brand Loyalty, Consumer Buying Behavior, Commitment to Society.

JEL Classifications: M31

DOI: $10.7176 / \mathrm{EJBM} / 12-36-02$

Publication date: December $31^{\text {st }} 2020$

\section{Introduction}

Tesco for Schools, Box Tops for Education, TOMS shoes and Live Strong are a few of the most popular Cause Related Marketing (CRM) campaigns today. They are campaigns that help organizations and others in need. But what exactly is cause marketing? In simple terms CRM, can be viewed as a partnership between a nonprofit and a for-profit organization for mutual profit. It can be argued that cause marketing started in the 1960s or the 1970s. Some say it started in the 1960s with the Jerry Lewis Telethon and Muscular Dystrophy Association, others say the 1970s when Bruce Burtch organized fundraisers between Marriott Corporation and the March of Dimes (http://topnonprofits.com/3-constituent-personas-that-nonprofit-content-marketers-should-target/accessed April 6, 2017).

The actual term was coined back in the early 1980s when American Express promised to donate $\$ 1$ to the renovation work of the Statue of Liberty every time one of its cards were used. There are several recent examples of CRM practice for example the CRM campaign launched by Tommy Hilfinger which raised over $50 \%$ to Breast Health International (Müler, Fries and Gedenk 2014), eBay's "Giving Works" campaign which raised more than half a billion of US dollars for charities (Andrews et al. 2014).

Butnariu (2007) defined the word "cause" as an action, event or a motive that triggers, motivates or stems something else to happen. Varadarajan and Menon (1988) defined the term as the practice of donating a specific amount from product sales to specific charitable causes. CRM activity can take the form of joint funding and promotion in which a firm's sales are linked (and a percentage of the sales revenue is donated) to a charity or other public cause. There are several typologies of CRM practice for example point of sale, purchase or action triggered donation, licensing, message promotion, employee engagement and digital programs.

According to Koschate-Fischer, Stefan and Hoyer (2012) CRM has become the fastest-growing strategy for sponsorship in the US. A number of studies aimed at revealing consumer attitudes and behavior regarding CRM campaign. For example, Nan and Kwangjun (2013) carried out a study using controlled experiment which demonstrated that an ad with an embedded CRM message compared with a similar one without a CRM message, elicits more favorable consumer attitudes towards the organization. The same study provided evidence to suggest that when the embedded CRM message involves high versus low brand / cause fit, consumer attitudes toward the ad and the brand are more favorable but only when the consumers are high in brand consciousness. Ross, Patterson and Stutts (1992) investigated gender and proximity effects in CRM and showed that females are more favorably inclined than males toward firms that employ CRM. Barone, Miyazaki and Taylor (2000) posit that there is little evidence to support the claim that consumers are likely to select brands offered by companies that engage in CRM. To this end the present study aims at shedding some light onto the perceptions held by Jordanian consumers regarding brands that support social causes.

\section{Literature Review}

CRM can take many forms ranging from point of purchase campaigns, to event sponsoring. A number of businesses have formed a social partnership with causes and charities for mutual benefit. Barone, Norman and 
Miyazaki (2007) support that even though marketers tend to rely more heavily on CRM strategies to increase sales there is disagreement regarding whether a retailer should partner with causes offering high or low fit levels with its core business practices.

This current paper aims at understanding the influence of CRM or as is it widely known "cause marketing" on the brand image among customers in Jordan within three variables which are: Purchase Intention, Solidarity Purchase and Brand Loyalty. The main question of the study will be "To what extent can CRM be influential on the brand image in terms the intention to buy, the solidarity buying and the brand loyalty?"

The concept of CRM is becoming one of the hot topics specifically through the last decade. It is becoming more and more apparent among companies specifically after realizing the kind of effect that it has over the success and prosperity of the enterprise. The very first definition for the term CRM, or as it will appear in this paper (CRM) was first defined back in 1988 by Varadarajan and Menon who were considered as the pioneers in this field, the authors defined CRM as "The process of formulating and implementing marketing activities that are characterized by an offer from the firm to contribute a specified amount to a designated cause when customers engage in revenueproviding exchanges that satisfy organizational and individual objectives" (Shabbir, et al 2009: p. 1231). Biglione and Woods (2007) defined CRM as "A way to promote strategic alliances between companies and civil society organizations (CSOs), stimulating social investment and mobilizing consumers and all of society to contribute towards different social causes" (IDIS, 2007, P. 2). And one of the early definitions for the term was the one which was presented by Varadarajan and Menon in 1988 as an early unpolished definition referring to "A new form of corporate philanthropy based on the rationale of profit-motivated giving" (Varadarajan and Menon, 1988). The authors in that definition have used the word "Philanthropy" as a reference to the voluntary deeds that a company does to community. From another perspective Anghel and others (2011) define CRM as "A commercial activity by which business and charities or causes form a partnership with each other to market an image, product or service for mutual benefit" (Anghel, et al 2011. P. 73). According to Bronn and Virioni (2001) CRM is something that every corporate has to do as a form of corporate social responsibility which refers to "The policy and practice of a corporation's social involvement over and beyond its legal obligations for the benefit of the society at large" (Bronn \& Virioni, 2001. P. 209).

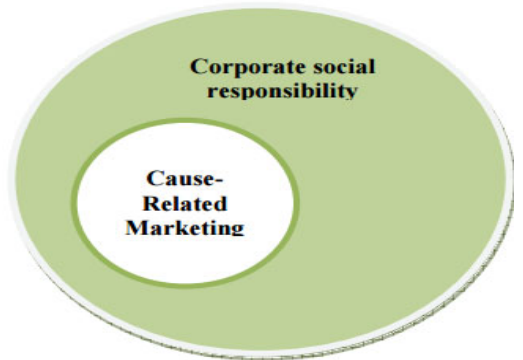

Figure 1: CRM is a part of social responsibility (Anghel)

The very first attempt to market for a cause or to initiate a CRM campaign was done by The American Express Corporate back in 1983. The corporate at that time have raised funds for the preservation of the statue of liberty. In no more than 4 months, the corporate managed to raise $\$ 1.75$ million for that cause and its benefits went up to 28\% (Laszlo \& Lyons, 2014).

\section{The nature of CRM based on current business practices}

However, there are several types of CRM, according to Sinčić Ćorić et al. (2011) there are three types of CRM and these are the traditional, event sponsoring and fundraising. The 'traditional' CRM type refers to when a percentage of the selling price of a product is donated to a charity. It produces a mutual benefit for both the business and the charity since on the one hand the business can generate more sales and achieve repeat purchase and on the other hand, it creates awareness for the cause/charity An example of traditional CRM is Yoplait's campaign "save lids, save lives" for breast cancer (Grome, 2013). According to Kuzma and Kuzma (2009), event sponsoring of sponsorship is a marketing tool that is used by many companies where the company provides monetary of support services for a certain cause or even for the sake of getting the needed promotional benefits and at the same time support the cause of the event. Another type of CRM is the fund raising which was defined by Zheng (2012) as the collection of monetary benefits for a certain cause by organizations and companies which seeks to get more attention from the public and the same time achieve the social responsibility which would increase their brand's popularity among customers.

In practice, CRM campaigns can take many forms CRM depending on the nature, objectives and creativity of the partners. For example, for over seven years, Starbucks has formed a partnership with (RED) to raise funding for the Global Fund to Fight AIDS on World AIDS Day. As part of the campaign, Starbucks donates 10 cents for every handcrafted beverage sold in participating U.S. and Canada stores, and raised over $\$ 12$ million in donations. The red cup ensures the consumers' commitment, resulting in increased brand loyalty. This CRM type is classified 
as "portion of purchase". Warby Parker has integrated the "buy one give one model" into their business strategy. For every pair of glasses Warby Parker sells, they donate a pair of glasses to their nonprofit partners-with over 1 million glasses given out so far. This is an example of a "buy one give one" CRM campaign. Walmart and Sam's Club have join forces and formed a social partnership to support the Children's Miracle Network Hospitals for over 27 years and in the process they have managed to raise over $\$ 750$ million in donations. For six weeks of the year, Walmart employees solicit donations for the cause from customers at checkout. For a dollar donation or more, consumers can put their name on a Miracle Balloon or dedicate it to a loved one. In 2012, the campaign was estimated to raise $\$ 122$ per minute ("point of sale" CRM campaign). Jeep established the S.A.F.E. return fund to provide secure transport of troops and supplies, aid for transition to civilian life, freedom-celebrating homecoming events, and enduring care of wounded veterans. In total, Jeep has given over \$1 million in donations and vehicles to the USO. In 2013, Jeep created a heartfelt Super Bowl commercial to help raise awareness of their commitment to the troops and their families. This CRM campaign is the "proud supporter" type (prosepad.com/blog/CRM/accessed April 5, 2017).

\section{CRM as a tool for brand image building}

Lindberg (2010) defines 'brand image' as the perception customers have towards a certain brand based on the brand's associations stored in the customers' minds. Maurya (2012) and (SondohJR et al, 2007) support that brand image is everything that people associate with a certain brand, including feelings, attitudes, perceptions, and decisions.

Heidarian and Bijandi (2014) studied CRM the role of CRM in creating a positive brand image among 260 customers in Tehran. The study's findings revealed that CRM has a positive impact on the brand image especially among skeptical customers who are rather hesitant in buying the brand. The study also revealed that customers' perceptions are also shaped by the perceived business motives behind the CRM campaign. If the company's motives in engaging in a CRM activity are perceived to be genuine then customers are more receptive to it. Another study carried out by Qamar (2013) aimed at understanding the role of CRM in motivating customers in Pakistan to purchase the brand associated to the cause. The study revealed that the majority of customers would buy it CRM.

\section{The study's hypotheses}

There is a statistically significant influence of CRMCRM on the perceived brand image among Jordanian customers.

Heidarian and Bijandi (2015) and Hajikarimi, Arabkoohsar and Omeyr (2014) argued that advertising is a critical promotional tool which can have a potential positive impact on instilling positive consumer perceptions towards the brand. However, one could also claim that some consumers may sometimes be critical and tend to look with suspicion the business efforts to associate its name with a cause or a charity and even more so when it invests in promoting these efforts. Qamar (2013) stipulates that CRM has the potential to create a positive brand image which in turn influences positively the customers' intention to purchase the brand in question.

This leads to the sub-hypothesis that follows below:

There is a statistically significant influence of CRM on the purchase intention among Jordanian customers.

According to Qamar (2013) CRMCRM positively influences the intention of customers to buyCRM. Dwivedi (2016) puts forward another perspective one that suggests that CRM is a communication tool which has the potential to encourage consumers to CRMbuy a certain brand. To this end, Shabbir et al. (2010) suggest that CRM is in essence creating awareness in relation to the brand and the brand's values and subsequently creates the intention of purchase.

There is a statistically significant influence of CRM on the solidarity purchase among Jordanian customers.

The word solidarity refers to a united set of feelings, actions, or agreement between members or individuals who have a common cause or a common interest. According to Martino, Giacchè and Rossetti (2016) the solidarity purchase is a state where group of people purchase a certain item due to its cause like for example when people purchase products that supports cancer patients because they have a cancer patient in their family, or women who purchase items which supports the fight for violence against women because they have been exposed to violence themselves. On the other hand, Galán - Ladero and Galera - Casquet (2015) argued that solidarity purchase can appear in different aspects, among these aspects is when a store assigns a space for the collection of donation or purchasing items like food samples and Christmas cards. Nadiri and Tumer (2011) and Ferrell (2011) argued that solidarity purchase influences the intention of the customer to buy a certain brand. Vineyard (2014) claims that solidarity purchasing is influenced by favorable word-of-mouth communication which can be triggered by the business engagement in CRM..

There is a statistically significant influence of CRM on brand loyalty among Jordanian customers.

Several authors such as Van den Brink, Odekerken-Schröder and Pauwels (2006); Hunjra, Azam and 
Humayoun (2012); Hasan (2016) and Srinivasan and Mahalakshmi (2015) support that there is a close relationship between CRM and brand loyalty.

\section{Methodological approach and theoretical framework of the study}

In this section you need to explain how you arrived at the proposed theoretical model (study model - please don't use the term instead use the term "theoretical framework") by making reference to the relevant CRM literature that is, any previous studies that have shed light onto the variables that you have incorporated in the study.

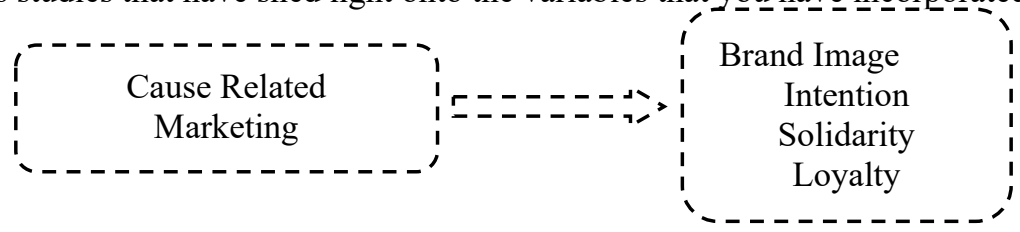

Figure (2): model and variables of the study

The theoretical framework adopted in the study links CRM with three variables that are related to brand image namely, the intention to buy, solidarity purchasing, and brand loyalty). The solidarity purchasing here can be also called the sympathy purchase which refers to the state where an individual buy a certain item from a certain band as a form of sympathizing with its cause (Fonte, 2013). However, researchers used the quantitative research methodology since the aim of the study was to study the perceived relationship between CRM campaigns and the three variables related to brand image. Convenience sampling was used in order to draw a sample of (350) shoppers from shopping malls and trading in Amman, the capital of Jordan. The researcher - luckily - was able to retrieved 300 properly filled questionnaires which were suitable for the statistical processing.

The key data collection instrument used was a questionnaire that was designed in a way that would reveal information in relation to the respondents' demographic characteristics such as gender, age, educational level, and income) and the respondents attitudes, perceptions, beliefs and opinions in relation to purchase intention, solidarity purchase and loyalty to brand. The questionnaire was based on a 5 point likert scale (strongly agree, agree, neutral, disagree, and strongly disagree). A Cronbach Alpha test was used to ascertain the instrument's reliability. The value was $=84.2 \%$ for the questionnaire. All values are accepted since they are more than 60\% (Malhotra, 2004).

The data which was retrieved from the questionnaire was processed and treated through the SPSS (Statistical Package for Social Sciences). Through SPSS formulas, descriptive analysis was done on the data in addition to the hypotheses testing that included simple regression of each hypothesis presented in this paper.

\section{The study's findings}

Demographic characteristics of the respondents

\begin{tabular}{|c|c|c|}
\hline Category & Frequency & Percentage $\%$ \\
\hline \multicolumn{3}{|c|}{ Education } \\
\hline Diploma or less & 21 & 7.0 \\
\hline Bachelor & 191 & 63.7 \\
\hline Master & 78 & 26.0 \\
\hline PHD & 10 & 3.3 \\
\hline Total & 300 & 100.0 \\
\hline \multicolumn{3}{|c|}{ Gender } \\
\hline Male & 180 & 60.0 \\
\hline Female & 120 & 40.0 \\
\hline Total & 300 & 100.0 \\
\hline \multicolumn{3}{|c|}{ Income } \\
\hline Less than $\$ 500$ & 15 & 5.0 \\
\hline$\$ 501-1000$ & 141 & 47.0 \\
\hline$\$ 1001-1500$ & 55 & 18.3 \\
\hline Above $\$ 1500$ & 89 & 29.7 \\
\hline Total & 300 & 100.0 \\
\hline \multicolumn{3}{|c|}{ Age } \\
\hline Less than 23 years & 27 & 9.0 \\
\hline 24-29 years & 119 & 39.7 \\
\hline $30-35$ years & 129 & 43.0 \\
\hline Above 36 years & 25 & 8.3 \\
\hline Total & 300 & 100.0 \\
\hline
\end{tabular}

Table (1): Sample distribution according to demographic variables 
The table above indicates that $21 \%$ of the sample had a diploma or a lower qualification whilst $63.7 \%$ of the sample had a bachelor degree, and the rest had a higher qualification. The participants' demographic characteristics show that the sample is educated, which can suggest that they may be more supportive and receptive of CRM campaigns. Jeddi and Zaiem (2010) claim that individuals with a high educational level are more likely to purchase a brand associated to a cause rather than consumers with a lower educational level. $60 \%$ of the present study's sample was male and $40 \%$ were female. As for the gender related results, it appeared through the analysis that men formed most of the responding individuals due to the nature of the population of the study at the time of distributing the questionnaire, however, and in reference to gender issues Moosmayer (2010) highlighted in his study that women were more interested in CRM compared to men, and the amount of donations that appeared from women were larger than those appeared by men. From another perspective, it can be said that considering the application process took place within the malls and the commercial complexes where families are shopping, it was the man who answered the questionnaire not the woman. A study carried out in Iran, by Zenyali and Safarnia (2012) revealed that CRM has a stronger impact on men rather than women subsequently motivating them to buy the brand associated with the cause. The majority of the respondents (47\%) earn between \$501-1000 per month whereas CRM only 5\% of the sample earns less than $\$ 500$ per month. People's income has a direct impact on their willingness to engage in charitable activities such as donations as appeared by Mohiuddin and Mohiuddin (2008) whoa argued that the income of an individual contributes to their intention to take part in CRM approach while Johansson, Nordine and Liljenberg (2015) argued that the income $\mathrm{f}$ an individual can deeply influence their behavior towards CRM and the idea of purchasing a certain item to support a certain cause.

\section{The study's findings}

The section below discusses the findings that emerged from the empirical analysis and is built around a set of propositions that are founded on the specific hypotheses. The discussion is founded analysis is based on the mean and standard deviation.

\section{(1) CRM positively influences the customers' perceptions regarding the brand image}

The descriptive analysis of the study's findings reveals that CRM has a positive influence on the brand's image since the means of the statements are above the mean of the scale (3). The statement that received the highest number of responses was: "I think that most companies use CRMCRM for profit purposes only" with a mean of (4.43). The statement that received the second highest mean was: "I do respect companies which participate in local community service" with a mean of (4.10). The study reveals that it is perceived that businesses engage in $\mathrm{CRM}$ in order to maximize their profits and not for altruistic reasons. What is interesting though is that the statement that received the second highest mean reveals that consumers tend to respect those businesses that engage in CRM activities. Is not a matter of "why" businesses engage in CRM but rather the fact that they actually do. Perhaps customers have accepted the fact that any business motivation is profit-oriented and are not negatively influenced. Instead, they tend to respect more those businesses that have an interest and actively engage in CRM activities. Several authors such as Heidarian and Bijandi (2015) and Hunjra, Azam and Humayoun (2012) have revealed through their research that there is a positive relationship between brand image and CRM.

(2) CRM positively influences the customers' purchase intention towards the brand associated with a cause The descriptive analysis showed that the statement "I think that this kind of marketing is a form of social contract between the company and the society so I am willing to purchase their goods" scored the highest (4.38) followed by the statement "I am not willing to buy a brand associated with a cause because I know that it will never achieve the claimed objectives" (4.10). The two most highly ranked statements reflect opposite views. The first statement demonstrates that CRM has the potential to increase the consumer's intention to purchase the brand associated with a cause or charity. This finding corroborates with Qamar's (2013) study, which showed that "CRM campaigns contribute towards consumers ' purchase intention" (p. 633). Corbishely and Mason (2011) found that CRM has a positive influence on the purchasing behavior of respondents and that customers were more "responsive" to CRM campaigns depending on the nature of the cause. A finding which agrees with the findings that emerged from the present study. In particular, the present study found that the customers who were 30-41 years old seemed to be more interested in buying products associated with a cause and had positive attitudes towards the CRM concept itself compared to the other age groups that participated in the study.

\section{(3) CRM influences solidarity purchase among customers}

The descriptive analysis showed that CRM does not have a positive influence on solidarity purchasing. Which was defined previously as a united set of feelings, actions, or agreement between members or individuals who have a common cause or a common interest? According to Martino, Giacchè and Rossetti (2016) the solidarity purchase is a state where group of people purchase a certain item due to its cause like for example when people purchase products that supports cancer patients because they have a cancer patient in their family, or women who purchase items which supports the fight for violence against women because they have been exposed to violence themselves The statement that scored the highest was "I don't support that kind of marketing because I am sure the money will not be used for the promoted reason" with a mean (4.03). This finding suggests that consumers tend to be 
critical and suspicious of marketing efforts undertaken by businesses aimed at supporting causes/charities. The second most preferred statement was: "I only buy the brand if the cause is justified" with a mean of (3.92). It seems that the cause's perceived attractiveness will influence consumers' attitudes towards the CRM campaign.

(4) CRM influences the loyalty towards the brand among customers

All the statements associated with this relationship scored CRM higher than (3) on the scale. The statement that received the highest score was: "Companies that support their society through activities such as CRM reflect their responsibility towards the society" (4.37). The statement that received the second highest score was: "I always buy the brand(s) that address my needs and supports the society" (3.92). This is supportive to what Hunjara et al. (2012) revealed in their study which was that CRM campaigns have a positive influence on brand loyalty and subsequently on brand sales. Adiwijaya and Fauzan (2012) found that CRM campaigns have the potential to increase customer satisfaction and subsequently, brand loyalty.

\section{Hypothesis testing}

The table below shows the results that emerged from hypotheses testing.

\begin{tabular}{|c|c|c|c|c|c|c|c|c|}
\hline Hypothesis & $\mathrm{R}$ & $\mathrm{R}$ Square & $\mathrm{F}$ & $\mathrm{Sig}$. & )Constant & $\mathrm{B}$ & $\mathrm{t}$ & Sig. \\
\hline brand image & .575 & .331 & 147.178 & $.000^{* *}$ & 2.241 & 0.411 & 12.132 & $.000^{* *}$ \\
\hline purchase intention & .497 & .247 & 97.555 & $.000^{* *}$ & 2.117 & .433 & 9.877 & $.000^{* *}$ \\
\hline solidarity purchase & .295 & .087 & 28.315 & $.000^{* *}$ & 2.868 & .245 & 5.321 & $.000^{* *}$ \\
\hline brand loyalty & .597 & .357 & 165.257 & $.000^{* *}$ & 1.780 & .547 & 12.855 & $.000^{* *}$ \\
\hline
\end{tabular}

**significant at 0.01

\section{Table (2): Hypotheses Testing}

H1: There is a statistically significant influence of CRM on the brand image among Jordanian customers. Simple Regression is used to test above hypothesis; it is found that a calculated value of $(\mathrm{F})$ is significant at $(0.05)$ level. This means that null is rejected, which means that there is a statistically significant influence of CRM on the brand image among Jordanian customers with moderate Pearson correlation 0.575 . This idea was examined by Hajikarimi et al. (2014) when they tried to understand the influence of CRM with the mediating role of firm motivations, social responsibility, and perceived quality among consumers. The present study measured the relationship between CRM and brand image and found it to be positive.

H2: There is a statistically significant influence of CRM on the purchase intention among Jordanian customers.

Simple Regression is used to test above hypothesis; it is found that a calculated value of $(\mathrm{F})$ is significant at $(0.05)$ level. This means that null is rejected, which means that there is a statistically significant influence of CRM on the purchase intention among Jordanian customers with moderate Pearson correlation 0.497. The present study showed that when a brand is supporting a cause/charity customers are more willing to purchase it. This finding is conducive with the findings that emerged from Fianto's (2014) study.

H3: There is a statistically significant influence of CRM on the solidarity purchase among Jordanian customers.

Simple Regression is used to test above hypothesis; it is found that a calculated value of $(\mathrm{F})$ is significant at $(0.05)$ level. This means that null is rejected, which means that there is a statistically significant influence of CRM on the solidarity purchase among Jordanian customers with week Pearson correlation 0.295 . The study corroborates the findings that emerged in previous studies such as Galan-Ladero (2012, 2013). Galan-Ladero (2012, 2013) revealed that the size of the donation made by a business to a cause/charity (CRM) has the potential to increase the level of solidarity (sympathy) purchasing and have a positive influence on brand loyalty.

H4: There is a statistically significant influence of CRM on the brand loyalty among Jordanian customers. Simple Regression is used to test this hypothesis. It is found that a calculated value of $(\mathrm{F})$ is significant at $(0.05)$ level. This means that null is rejected, which means that there is a statistically significant influence of CRM on the brand loyalty among Jordanian customers with moderate Pearson correlation 0.597 . This finding is supportive of the existing CRM literature (Long et al, 2013).

\section{Theoretical and Managerial Implications}

The present study has generated some interesting findings which have both theoretical and practical implications and corroborate the current knowledge on CRM. It seems that by associating a brand with a cause/charity (CRM campaign) businesses have the potential to influence positively the perceptions held by consumers towards the 
brand, the corporation and subsequently their purchase intention, consumption behavior and brand loyalty.

Some of the participants perceive CRM to be an 'expression' of the commitment that a company has towards the society whilst others perceive it as a 'social contract' between the company and the society. It seems that CRM campaigns are seen as strategies aimed at enabling the business to achieve its profitability goals whilst benefiting the society's well-being. The consumers studied are keen to support and buy a brand associated with a cause/charity. They are also willing to repeat their purchase and remain loyal to the brand.

The study revealed that in general that the customers in Jordan understand the underlying ideas of CRM concept. In addition to that, they were able to locate their attitudes towards the concept in regard to their own personality and beliefs, this appeared through their initiative to sympathize with a certain CRM approach compared to another which is a good indicator to the degree of knowledge that the Jordanian customers have. In another meaning, the study findings highlighted a good degree of understanding among Jordanian citizens to the concept of CRM.

It is recommended through the current study to carry out another study which takes into perspective the influence of CRM as a marketing approach in increasing the awareness of citizens of the importance to support their community members who are in need. Also it is recommended to examine the influence of the organizations' participating and taking part in sponsoring events and supporting fundraising event and to what extent may this action influence their image among citizens and increase their popularity in addition to showing them as much supporting to the social responsibility as possible.

Generally speaking, choosing the cause that best suits the society might be able to grab the attention of the customers towards the brand and the organizations behind it. It is important here that the issue if solidarity purchase or as it might be called the sympathy purchasing is something that is really critical and worth to be studies in a deeper way, the managers may look into the concept of what may provoke the customer to buy a certain brand out of sympathy and caring and what might make them to believe in a certain brand in accordance with the cause that it is marketing through.

\section{References}

- $\quad$ Adiwijaya, K. and Fauzan, R. (2012). "Cause-related Marketing: The Influence of Cause-Brand Fit, Firm Motives and Attribute Altruistic to Consumer Inferences and Loyalty and Moderation Effect of Consumer Values". Singapore: IACSIT Press, pp.49-54.

- Andrews, M., Luo, Xueming, Fang, Z. and Aspara, J. (2014) "Cause Marketing Effectiveness and the Moderating Role of Price Discounts” Journal of Marketing, 78(6), pp. 120-142.

- Anghel, L., Grigor, G. and Rosca, M. (2011). "Cause-Related Marketing, Part f Corporate Social Responsibility and Its Influence upon Consumers' Attitude". [online] Available at: https://core.ac.uk/download/files/153/6678277.pdf [Accessed 15 Jun. 2016].

- $\quad$ Babu, M and Mohiuddin, M. (2008). "CRM and Its Impact on the Purchasing Behavior of the Customers of Bangladesh: An Empirical Study”. AIUB Bus Econ Working Paper Series, No 2008-05. [online] available at: http://orp.aiub.edu/WorkingPaper/WorkingPaper.aspx?year=2008 [accessed 15 June 2016.

- $\quad$ Barone, M.J., Miyazaki, A.D. and Taylor, A.K. (2000) "The influence of CRM on Consumer Choice. Does one good turn deserve another" Journal of the Academy of Marketing Science. ISSN: 0092-0703.

- Biglione, A and Woods, M. (2007). "CRM, Guidelines, and Cases". [online] Available at: http://www.csr360gpn.org/uploads/files/resources/CRM_Guide.pdf. [accessed 15th Jan 2016]

- $\quad$ Bronn, P and Virioni A. (2001). "Corporate social responsibility and cause-related marketing": an overview. [online] available at: http://home.bi.no/fg196053/csrandCRM2.pdf. accessed 14th Jan 2016 [accessed 15 June 2016]

- $\quad$ Butnatiu, C and Veale, T (2007). "On the Categorization of Cause and Effect in WordNet". [online] available at: http://afflatus.ucd.ie/Papers/GWC08_CauseEffect.pdf. accessed 20th Jan 2016. [accessed 15 June 2016]

- Corbishley, K. and Mason, R. (2011). "Cause-related marketing and consumer behavior in the greater eThekweni area”. Journal of Business Maangement, 5(17), pp.7232-7239.

- C Corić, D., Živadinović, N. and Dropuljić, M. (2011). "The effects of cause and donation size of cause-related marketing program on consumers' intention to buy”. University of Zagreb. Research paper series, 11(8).

- DwiveDi, A. (2016). "Influence Of CRM On Consumer Purchase Decisions". Pristine International Journal of Management Research, 1(1).

- Ferrell, Erika, "Consumer's Motivation For Purchasing Fair Trade Clothing" (2011). Theses and Dissertations-- Retailing and Tourism Management. Paper 1. http://uknowledge.uky.edu/mat_etds/1

- $\quad$ Fianto, A., Hadiwidjojo, D., Aisjah, S. and Solimun, (2014). "The Influence of Brand Image on Purchase Behavior through Brand Trust”. Business Management and Strategy, 5(2), pp.58-76.

- Fonte, M. (2013). "Food consumption as social practice: Solidarity Purchasing Groups in Rome, Italy". Journal of Rural Studies, 32, pp.230-239. 
- Galan-Laddero, M and Galera-Casquet, C. (2015). The Role Of The Retailers

- Galán-Ladero, M. and Galera-Casquet, C. (2012). "Does The Donation Size Influence On Attitudes Toward Cause-Related Marketing? ”. Journal of Responsibility and Sustainability, 1(1), pp.7-19.

- Galan-Ladero, M., Galera-Casquet, C., Valero-Amaro,, V. and Barroso-Mendez, M. (2013). "Does The Product Type Influence On Attitudes Toward Cause-Related Marketing?". Journal of Economics \& Sociology, 6(1), pp.60-71.

- $\quad$ Grome, L. (2013). Cause-Related Marketing Campaigns Corporations \& Nonprofits: Whose Brand Benefits?. [online] Available

at: https://conservancy.umn.edu/bitstream/handle/11299/167448/Grome,\%20Lindsay\%202013.pdf?sequence= 1\&isAllowed=y [Accessed 15 Jun. 2016].

- $\quad$ Hajikarimi, A., Arabkoohsar, S. and Omeyr, A. (2014). "Examining the effect of Cause-related marketing on Brand image with the help of Firm motivation, Social responsibility, and Perceived quality as mediating variables". Applied mathematics in Engineering, Management and Technology, 2(4), pp.272-279.

- Hasan, M. and Rahman, A. (2015). "Impact of CRM on Brand Loyalty: An Empirical Study on Telecom Industry of Bangladesh". A Journal of The Institute of Cost and Management Accountants of Bangladesh, 3(1).

- Heidarian, E and Bijandi, M (2014). "The Role of Cause-Related Marketing on Brand Image Perception in the Garment Industry". [online] available at: http://ijamae.com/wp-content/uploads/2015/03/1.pdf. accessed 22nd Jan 2016. [accessed 15 June 2016]

- Heidarian, E. and Bijandi, M. (2015). "The Role of Cause-related Marketing on Brand image Perception in the Garment Industry". International Journal of Academic Research in Business and Social Sciences, 5(6), pp.416-422.

- $\quad$ Hunjra, A., Azam, R. and Humayoun, A. (2012). "CRM and its Impact on Sales: Mediating by Brand Loyalty and Customer Purchase Intention". SSRN Electronic Journal. [online] Available at: http://dx.doi.org/10.2139/ssrn.2130320 [Accessed 15 Jun. 2016].

- $\quad$ Hunjra, A., Azam, R. and Humayoun, A. (2012). "CRM and its Impact on Sales: Mediating by Brand Loyalty and Customer Purchase Intention". SSRN Electronic Journal.

- In Cause-Related Marketing: A Reference To The Spanish Case. Available online: http://dehesa.unex.es/bitstream/handle/10662/5698/1847-2206_28_1_97.pdf?sequence=1. Accessed $7^{\text {th }}$ June 2017

- $\quad$ Jedd, N. and Zaiem, I. (2010). "The Impact of Label Perception on the Consumer's Purchase Intention: An application on food products". IBIMA Business Review, 20(10), p.14.

- Johansson, L. Nordine, S and Liljenberg, C. (2015). The determining factors behind consumers' intention to participate in different types of Cause Related Marketing campaigns. Master's Thesis. Linnaeus University.

- $\quad$ Kim, H., Kim, J. and Han, W. (2016). "The effect of CRM in Company and Brand attitude". Seoul Journal of Business, 11(2), pp.84-117.

- $\quad$ Koschate-Fischer, N., Stefan, I.V. and Hoyer, W.D. (2012) "Willingness to Pay for Cause-Related Marketing: The Impact of Donation Amount and Moderating Effects", Journal of Marketing Research, 49(6), pp. 910 927.

- Kuo, A. and Rice, D. (2015). "The impact of perceptual congruence on the effectiveness of cause-related marketing campaigns". Journal of Consumer Psychology, 25(1), pp.78-88.

- Kuzma, A and Kuzma, J. (2009). "Corporate Sponsorship in the Marketing Curriculum: A Preliminary Investigation". Journal of Instructional Pedagogies. 1(2).

- Laszlo, M and Lyons A (2014). "Strategic Alliance and Make-A-Wish: A Case of Cause-Related Marketing”. [online] available at: https://spea.indiana.edu/doc/undergraduate/ugrd_thesis2014_pnmgmt_laszlo.pdf. [accessed 15 June 2016]

- Lindeberg, A. Blomkvist, C and Johansson, M. (2010). "Understanding the relationship between Brand identity and Brand image- A case study of Coop". [online] available at: https://www.divaportal.org/smash/get/diva2:530562/FULLTEXT01.pdf. [accessed 15 June 2016]

- $\quad$ Long, C. Khalafinezhad, R. Ismail, w and Rasid, A. (2013). Impact of CRM Factors on Customer Satisfaction and Loyalty. Asian Social Science. 9(10).

- Malhotra, N. K. (2004). "Marketing Research". New Jersey: Prentice Hall

- Martino, G. Giacchè, G and Rossetti, E. (2016). Organizing the Co-Production of Health and Environmental Values in Food Production: The Constitutional Processes in the Relationships between Italian Solidarity Purchasing Groups and Farmers. Journal of Sustainability. 8(4). P. 316

Maurya, U. and Mishra, P. (2012). "Is a brand? A Perspective on Brand Meaning". European Journal of Business and Mangement, 4(3).

- Mohiuddin, M and . Mohiuddin, M. (2008). Cause Related Marketing and Its Impact on the Purchasing Behavior of the Customers of Bangladesh: An Empirical Study. AIUB Bus Econ Working Paper Series, No 
2008-05, http://orp.aiub.edu/abewps-2008

- Moosmayer, D. and Fuljahn, A. (2010). "Consumer perceptions of CRM campaigns”. Journal of Consumer Marketing, 27(6), pp.543-549.

- $\quad$ Müller, S.S., Fries, A.J. and Gedenk, K. (2014) "How much to give? The effect of donation size on tactical and strategic success in cause-related marketing”, International Journal of Research in Marketing, 31(2), pp. 178-191.

- $\quad$ Nadiri, H. and Tümer, M. (2010). “Influence of ethnocentrism on consumers' intention to buy domestically produced goods: An empirical study in North Cyprus". Journal of Business Economics and Management, 11(3), pp.444-461.

- Nan, X. and Heo, K. (2007) "Consumer responses to corporate social responsibility (CSR) initiatives: Examining the role of Brand-Cause Fit in Cause-Related Marketing” Journal of Advertising, 36(2).

- $\quad$ Qamar, N. (2013). "Impact of CRM on Consumer Purchase Intention: Mediating Role of Corporate Image, Consumers’ Attitude and Brand Attractiveness”. Middle-East Journal of Scientific Research, 16(5), pp.633643.

- $\quad$ Ross, J., Patterson, L. and Stutts, M. (1992). “Consumer perceptions of organizations that use cause-related marketing". Journal of the Academy of Marketing Science, 20(1), pp.93-97.

- Shabbir, S., Kaufmann, H., Ahmad, I. and Qureshi, I. (2010). "CRM campaigns and consumer purchase intentions: The mediating role of brand awareness and corporate image". African Journal of Business Managemen, 4(6), pp.1229-1235.

- $\quad$ Shuriedeh, M., Shaltoni, A. and Hijjawi, D. (2014). "Marketing Communications Role in Shaping Consumer Awareness of Cause-Related Marketing Campaigns". International Journal of Marketing Studies, 6(2), pp.1918-2703.

- $\quad$ Sondoh, S., Omar, M., Wahid, N., Ismail, I. and Harun, A. (2007). "The Effect of Brand Image on Overall Satisfaction and Loyalty Intention in The Context of Color Cosmetic". Asian Academy of Management Journal, 12(1), pp.83-107.

- $\quad$ Srinivasan, R. and Mahalakshmi, S. (2015). "CRM and Store loyalty of Youngsters". Journal of Business and Management, 17(9), pp.29-35.

- $\quad$ van den Brink, D., Odekerken-Schröder, G. and Pauwels, P. (2006). "The effect of strategic and tactical causerelated marketing on consumers' brand loyalty". Journal of Consumer Marketing, 23(1), pp.15-25.

- Varadarajan, R and Menon, A. (1988). "Cause-Related Marketing: A Co-alignment of Marketing Strategy and Corporate Philanthropy”. Journal of Marketing. 52(3), pp. 58-74

- Vineyard, Cassidy L., (20140. "The Relationship Between Fashion Blogs and Intention to Purchase and Word of Mouth Behavior" . Textiles, Merchandising and Fashion Design: Dissertations, Theses, \& Student Research. Paper 4.

- Zeynali, S and Safarnia, H (2012). “Customers' Response to Cause-related Marketing: Empirical Evidence from Iran". Middle East Journal of Scientific Research. 12(7). Pp. 1012-1016

- Zheng, Y.(2012). A Case Study Examination into How Charities Enhance Fundraising Effectiveness through Managing Relationship with Donors and Beneficiaries. Master's Thesis. University of Exeter 